DOI: 10.2478/v10141-009-0039-4

\title{
Why the Olympic Modernism is more than Sport?
}

\author{
Andrzej Pawłucki
}

Academy of Physical Education and Sport in Gdańsk, Poland

KEYWORDS

\begin{abstract}
Olympic sport is a symbolic response to the literal evil of war. It establishes peace in its own way as there is always a need to redeem the evil of war. Sport is not what the mindful journalists think - a gathering of pagan mob, festival of youth or vanity fair of business traders. If, however, Olympic modernism ever became its own negation in the form of a spontaneous movement of liberation from moral constraints, legitimised by postmodern ideology, it would be a negation of the ethical ideal of friendship, i.e. it would be collective defiance of order as ordo amicitia pro pace. In consequence, Olympic modernism would deprive itself of the idea of universal good and lose its inherent order-making potential. Whoever then becomes a part of the motley movement against oneself, in which all standards of moral life in love are replaced by liberal aesthetic expressions, he or she becomes incomprehensible to oneself and others, like the proverbial black sheep in a family. Beware the poor in Olympic spirit of peace, as they will never be granted friendship. It will be a great loss to them as well as to the entire Olympic family. The Olympic Games of Peace must last as long as there are wars. The primary cause of Olympic sport is the experience of the evil of war. Olympic modernism uses sport as the foundation of its symbolic affirmation of the idea of friendship. It has not created sport, but has taken a great advantage of it, using the physical cultivation and the moral formation of the mighty sport club for free play (ludic sport) or paid play (professional sport). Although the Olympic costs are high, despite all the expenses, it is a highly profitable cultural enterprise. The order of friendship for peace, known as Olympic modernism, not only banishes the spectre of hatred but also provides culture with sanctity, making everybody's life more perfect.
\end{abstract}

sport, Olympism, modernism

\section{Why Olympic modernism is more than sport ?}

What is the difference between Olympic sport and so-called non-Olympic sport? It is a valid question I ask again and again in a flush of anger caused by ignorant sport "experts" in their ignorant comments ${ }^{1}$. The answer to this question may seem obvious; however, the existence of multiple cultural varieties of sport does not seem obvious to journalists representing opinion-making

\footnotetext{
${ }^{1}$ See, for instance, Kowalski, M. A. Występy kuglarzy (Conjurer Show), (Czas, 2008, 35-36). Since the end of the Beijing Olympics I have collected, with very little research effort, several comments by sports journalists, being popular opinions testifying to their authors' ignorance of sport philosophy.
} 
newspapers and magazines, who sneer at sport in general and - in particular, after the closing ceremony of the Beijing Olympics - dub Olympic sport as "contests for the barbaric rabble."

Following Coubertin, I would ask the media people the following question: Do you seek a fair at the lowest level of your ignorance, or a temple at the highest level of your wisdom?

For years you have been creating a false image of the Olympic village in the consciousness of your sport mob: the image of Olympic backwoods inhabited by no one but crooks and thieves. The International Olympic Committee in Lausanne is depicted by you as a gang of corrupt aristocrats. It is no surprise that this anti-Olympic crusade of literate but undereducated journalists, which depicts the Olympic games as a fair of vanity, corruption and trickery, has made the sporting community lose its communal identity. It has divested itself of the ethical ideal of community for friendship and acceded to a convenient and unpretentious form of tribal chauvinism.

The great community of the sports stadium represented by the stadium fanum is succumbing generation after generation - to the de-socializing activity of the usurpers of media power. They obviously plead their intellectual ability and accept with no reservation the understanding of Olympic sport as a joyful fest of youth. This way they close the doors to the salon of Olympic modernism and choose not to participate in the universal movement of friendship for a harmonious life in peace.

As a pedagogue I deplore the liberal colonization of the minds of athletes, coaches and the sporting community at large, through popular play and postmodern aesthetics of life are replacing the ethos of moral rigorism. ${ }^{2}$ I would like to argue here with a distinguished colleague of mine, who could not accept my justification of the superiority of Olympic sport over non-Olympic sport. ${ }^{3}$ I am more than eager to enter into this discussion and - adding fuel to the Olympic flames - I repeat that I consider Olympic sport to be one of those few enlightened movements that will grow long after we are all gone. I follow in the footsteps of Rev. Robert S. de Courcy-Laffan, a member of the IOC, who in the beginning of the Olympic movement was inclined to ridicule it, but then in 1908, in an act of miraculous self-conversion, became convinced that the final outcome of the Olympic movement would be hard to predict, even in one-hundred years. ${ }^{4}$

\section{Work as the primary cause of sport}

What was the cause of the emergence of Olympic sport and its meaning? What are the causes and meanings of other varieties and cultural types of sport? To answer these questions one may start with the etymology of the word sport itself to see how it was used to describe a certain designate. It can be, however, a rather inauspicious verbal measure confirming a number of dictionary definitions of the term, which are mostly etymologically unclear. By calling up some simple associations with the root $s$ (port), one can conjecture that the term is related to the word porta (Lat. gate) and deportation, i.e. putting players behind the city gates ${ }^{5}$ and consenting to allotment of an area for a city playing field.

\footnotetext{
${ }^{2}$ According to Kelvin B. Wamsley, the model of postmodern sport rejects the "moral restraints characteristic of the ethos of sport modernism", Laying Olympism to Rest, in: Post-Olympism (2005) Routledge, p. 222.

${ }^{3}$ See my comments from 2007 in Prawo pokoju olimpijskiego (Law of Olympic peace) in which I observed that the Olympic Games were something more than sport (Osoba w pedagogice ciała, Olsztyn 2007, OSW). My point of view, however, seems to be contested by J. Kosiewicz (see: Społeczne i kulturowe wartości sportu [Social and cultural values of sport], Warszawa 2007, AWF, p. 44).

${ }^{4}$ After D. Miller, Historia igrzysk olimpijskich i MKOL (History of the Olympic Games and the IOC), Poznań 2008, Dom Wydawniczy Rebis, p. 63.

${ }^{5}$ See PWN Oxford English, Wielki Słownik, Warszawa 2002, or Webster Dictionary, published by The New American Library, 1956 , The University English Dictionary (ed. R.F. Patterson, D. Litt), Roydon, and Latina Słownik, Buchmann, Toruń 2008, Literat.
} 
The lexical analysis is of little use here, if sport as play is not considered a part of a cause-andeffect order. One should rather ask: Who is the one who plays sport? or, first of all, What are the reasons behind taking up play called sport or - following the distinction made by Roger Caillois - play called agon?

Here I am taking the traditional approach to the meaning of the cause of sport as play, stipulating that in the linear sequence of events he who provides himself with sport as play must have been subjected to an earlier event, quite different than play but being its primary cause.

The following categorical clause is made possible by way of syllogistic understanding: Man is the subject of work but work in the objective sense is always there at the onset of life. ${ }^{6}$

First, in the social sense everyone is a subject of work, i.e. accumulating life-giving goods, according to the principle: if life is co-existence, one must - willingly or unwillingly - become an object of work, i.e. become a worker for oneself. Second, every worker in the objective sense tends to lose power and feel tired. Third, such a worker commences another act of work after having rested, and treats his next work commitment as a sensuous retraction from strenuousness, fatigue and discouragement, often in the form of exhaustion and disease. Fourth, the worker paradoxically returns to work by escaping from it, i.e. indulging in play.

It can be thus concluded that everyone is a man of work, and every worker becomes a man of play. Therefore, every man of work (or pretending to work as an amateur or a high-class idler) ${ }^{7}$, is a man of play. One can also add that man, like a coin, has two sides: the obverse of the working man and the reverse of the playing man; or that Homo laborens $r$ has always its Homo ludens side.

Certainly, the above logic would not have been plausible without the knowledge of empirically-based theories and my own experience. ${ }^{8}$ It would not have been possible for me to juggle with the words: work and play, if I had not known both concepts earlier and grasped the relationship between them. I follow Roman Ingarden who stipulated that an object must be grasped in its associations with other objects, so that a subject is able to place an object in a network of real associations with other objects. This is what I did when adding that a man who works and subdues the Earth must rest. This is why the Earth must be subject to the carnivalesque of life. A wearied Homo laborens must play to deliver himself from the chains of labour, conceiving new forms of entertainment and relaxation. An act of play comes after an act of work and precedes another act of work and so on. We play because we are entitled to play.

The primary source of sport lies in play, and play may take on the form of a contest, competition or even fight. In the Latin language area the term sport covered all these forms, although the word itself remained unknown for a long time, and had definitely been unknown in cultures earlier than Rome.

Sport as rest-in-play is an inherent element of work.

In conclusion, in order to get to know the primary cause of sport-play, i.e. its essential driving force, it must be placed in the relationship with another social being which precedes it in ontological time. The question about the subjectivation of play must be first preceded by an explanation of the

\footnotetext{
${ }^{6} \mathrm{I}$ am referring here to the distinction between work in the objective sense and work in the subjective sense made by Pope John Paul II in Laborem Exercens. It corresponds to the distinction between labour and work in the English language.

${ }^{7}$ For more on amateur sport see Osoba w pedagogice ciała, Olsztyn 2007, OSW.

${ }^{8}$ No specific citations. Literature on philosophy of work and play is extensive and widely available.
} 
nature of the primary cause of sport-play. In fact, man's participation in play seems to be a necessary consequence of man's participation in hard work.

Play as an inner cause is at the same time a consequence of some other outer cause. Since everything has its cause somewhere, so do sport-play and its institutional form of spectator sport. Journalists or even trainers (who consider themselves to be leading experts on sport) who think that discovering the truth about sport is possible through popular and insistent, phenomenological learning are deluded, like data collectors who think they can formulate a theory of a phenomenon on the basis of its sheer description.

It should be added that no phenomenon is a monad, i.e. its own cause and effect. Also, in social praxis, all manifestations of participation in culture are existentially interrelated, even those recognized in cultural sociology as autotelic. Play (and sport) is, in my opinion, a highly calculated existential act. It is a necessity, like a carnival, which comes after fasting, hard labour and toil. After the due rest-in-play man can then return to activities which are of primary existential importance.

\section{Sport as play at work}

Now let us take a look at two culturally highlighted versions of sport, as opposed to its original variant of local and ethnic play: spectator sport - considered from the perspective of spectators, also known as fans or supporters, who watch the agon; and professional sport - considered from the position of athletes (actors).

The agon has always been the property of spectators, who appropriated - with no commitments - the live images of emotional events staged by actors. A spectator is and always has been a worker who proceeds from one act of work to another, seeking a rest break and finding it in entertainment. This worker is then entertained in his role as a spectator; to find satisfaction he even pays extra to rest in play and forget the hardships of work. The spectator's constant demand for the spectacle has made the actors develop their agonistic skills to meet the spectator's expectations. The history of self-organizing agon has shown that both the actor and the spectator kept the spectacle moving. An agent was put in charge of the spectacle's organization; trainers were put in charge of the actor's stage preparation; and the audience manager was put in charge of the emotional well-being of spectators. The sports stadium was created with two common grounds for its participants: the pitch with stands (stage with seats), and the sports club (most significant from the sociological vantage point). The latter was founded to associate semi-professional athletes (an athlete did not cease to be a postman, butcher or police officer) - and at a higher institutional level - professionals and spectators. The aroused spectator, earning a living outside the stadium, spared no money to fund his own stadium entertainment. This way the athlete from the club was able to become a professional, and the relationship between the two became even stronger in the form of sporting fan club.

This was the dialectic origin of sport: the spectator becoming a sports fan, the athlete becoming a professional. Both were essential to each other. Both served each other, but also each was a servant to himself. How was that possible? The spectator by expressing his admiration of the athlete justified the latter's social existence. This is why the athlete had someone to live for, and the spectator was having fun by watching this life at the stadium. In this way, the worker from outside the stadium was provided with recreational entertainment. The sports fan "absorbed into the stadium" and faithful to the stadium play was faithful to the athlete and the club. The sports fan developed a new life and a new identity: of the fan of his own club bound to his place of birth or residence. The fan became a club member and in sports competition with the opponent's club he often betrayed the good values of sport and abused his spectator's status. By denying reciprocity to his own athlete he started a fight with a 
similarly degenerated fan of the opposing athlete. This degeneration of the sports fan was once explained as being a state of unsatisfied needs or a lost social identity. If so, then - leaving aside the notion of sports fans' sociopathology - one could assert that a perfect fan would be a worker with a firm professional identity and normalized moral relationships with the community. Psychologists say that anyone who is able to work and find peace in reciprocal love is happy. Thus the worker has become empowered to play the role of a perfect fan.

On the other hand, the athlete was strengthening his social position as he was seeing, like in a mirror, his hard-trained stage skills. The training became his work; he became a professional in his stage work on the sports field. The professional athlete became then a worker for the sports fan, i.e. for the worker outside the stadium.

\section{The paradox of carnival in sport}

If the syllogism about the man of work becoming the man of play is true, then what is play to the working athlete, i.e. the professional athlete? This question requires explanation as the above theorization should account for a very special case: the paradox of play at work. I was once asked this question by a famous coach known for imposing high and rigorous demands upon his athletes. He is so demanding that he leaves his athletes, i.e. "workers" no free time. From the spectator's standpoint the explanation is simple: the spectator comes to the stadium to enjoy himself after work - he constitutes the sport fanum. The athlete is his training, involving periods of resting and biotechnical restitution, comes to the stadium to work as a participant in the agon. And so on, and so forth: the professional athlete completes his acts of work in a training cycle, incorporated in the regular stadium schedule - from one contest to another. There is no play in it. We can thus say that an athlete who "works on stage" experiences work and play simultaneously, i.e. he becomes a participant in the carnival at work. After the carnival season the athlete is exhausted physically and emotionally and decides to take a break to experience play. A carnival can also be tiresome. It is paradoxical that the break the athlete takes becomes a break from his work, i.e. sports carnival. The athlete's play is, however, different from athlete's work (a resting football player never plays football when he is resting).

\section{The moral dimension of sports situation}

Like an unfaithful supporter, a professional athlete also betrayed himself, driven by his lust for feats, vain fame or sheer greed. He violated the stadium convention about mutual respect, but what is important, as a "dishonest worker" he was not able to meet the standards of fair play in a sports stadium. A dishonest/unfair worker is not able to play fairly as an athlete, but he has to. A feigned attempt to reach these standards is usually disclosed as sporting hypocrisy. Symbolically the unfair athlete receives a red card; and the unfair spectator is banned from entering the stadium. The athlete should remember that his absolute duty is to show unconditional respect to himself and his opponent.

In sport, in its strict sense, i.e. showing one's superiority over the opponent, the athlete must maintain his or her humanity. Regardless of the final result of sports competition - victory or defeat both sides of the sports contest, although different, must be morally equal to each other. Despite moral equality, which makes the athlete great in his or her humanity, the true and fair athletes must distinguish between the vanquisher and the vanquished, i.e. they must cause moral inequality. They seem to contradict themselves, but it is only apparent. The art of sport is to never lose one's fairness, never succumb to evil-doing, and always - which sounds almost impossible - flaunt one's decency as 
a testimony to the clearness of one's sporting conscience. Athletes should always keep this in mind, even when the temptation to win at all costs seems most important. Respecting one's own dignity gives rise to respecting the opponent's, referee's and supporter's dignity as participants in the sport stadium. An athlete who respects his humanity, i.e. who measures his quality with moral virtues, will always respect his opponent's humanity. He will love his neighbor as himself, and once he meets the standard of sporting humanity, the winner will always be sport, regardless of the outcome of the contest. The paradox of victory in humanity, i.e. a victory regardless of the final sport result, expressed in a well-known saying that there are no losers in sport, shows that there is an existential and humanistic value in spectator and professional sports. Thanks to the norm of fair play, sport can become self-fulfilled in fairness, even in most adverse circumstances. An athlete who calls upon the spectator as a witness of his fairness legitimizes the social utopia known as the sports family. At an even higher level of his achievements in humanity the athlete can reach the dignity of a member of the Olympic family. In this pursuit of moral self-fulfillment the athlete contributes to the idea of humanistic common good. In this way the athlete proves that his morality deriving from the age-long experience of ancient agon, medieval knight's tournament, amateur pastimes of the nobility, folk games and plays and the ethics of love of Olympic sport bring common good to life outside sport.

A humanist who sees moral tension in a sporting event extols it and presents it to the extrastadium community as proof of great ethical value. He is transported with delight on his discovery that, unbeknownst to him, the enlightened people of sport have reached the conclusion that sport demands fairness from all its participants, which is manifested in providing equal opportunities of victory to everyone.

This is the idealized mission of sport as envisioned by ethicists, who try to see the sense of the athlete's act in the collective intellectual effort of ideas of people of sport - in this accumulated, multidimensional culture of sport.

\section{(Re)discovery of sport by Pierre de Coubertin}

This was the train of thought followed by the young Pierre de Coubertin, who found a great delight in his discovery, like a boy seeking ideals in a strange world.

Thomas Arnold, headmaster of Rugby School (1828), would have been delighted as well, if he had been able to see how his pedagogy was extolled sixty years later in France, and how the 20-yearold Coubertin hoped for the moral elevation of his society through sport. This French seeker of educational novelties simply re-discovered the secret of English sport. Sport had existed before him and would have elevated its status in the European culture of play anyway, with or without Coubertin. However, this young enthusiast, deeply convinced about the chivalrous virtues and character of English sport, realizing the social values of games from New England, and inspired by the ancient games of Olympic gods decided to make his vision of sport with no limits truly international and breathe neo-Olympic life into sport.

This 20-year-old epigone of the old moral school of English sport first became convinced that - after all his thorough studies - sport enhanced the knightly spirit and built character ${ }^{9}$, and then in his search for explanation of Olympic sport, made an offer of integration in the friendship for peace to the humankind. He grew mature for many years after his enthusiastic speech at the Sorbonne - the intellectual center of enlightened Paris. Coubertin's speech might have seemed pretentious, trite and

\footnotetext{
${ }^{9}$ Statements taken from de Coubertin's speech at the Sorbonne, his articles and other public addresses, 18911894.
} 
commonplace to the academia of the time, when he sang the Hymn to Apollo and raised his glass to the return of the Hellenic Olympic spirit. It was, in fact, the first, but not the only, time he contradicted himself. He would extol the Christian spirit of brotherhood of all nations and their moral unity and pagan Olympic idols in the same breath. But this is not the point. As Bronisław Bilinski noted, Pierre de Coubertin's Olympism was not a monolith. Surely, the young Coubertin was not able see clearly the spirit he breathed into the neo-Olympic sport community together with his faithful friends. ${ }^{10}$

In his later cognitive development, following consecutive revelations on the mysterious horizons of the simplicity of sport, in his two speeches (Sorbonne 1894 and Athens 1895) Coubertin would present the world with his discovery of the spirit of sport. With the support of his mentor Father Henri Didon, Coubertin would later conceive the idea of internationalization of sport as a religion of brotherhood for peace, stating that "In the modern world threatened by decadence, the Olympic act can be considered a noble school of spiritual purity" (1927).

Coubertin's enthusiasm was contagious. In 1912, thanks to his numerous followers pursuing the understanding of the neo-Olympic sense of sport, the key symbol of the symbol was established. In his search of links with the ancients, Coubertin transformed the rings from the Delphi altar into a new semiotic order by placing them against the white background of the Olympic flag. The whiteness represented peace between different communities and nations, and the five colors of the rings interlocked in friendship reflected equality and brotherhood of these nations and communities.

Taking Coubertin's intellectual maturity into consideration, his determination about exclusion of women from the Olympic family is hard to understand. He would be consistent in his stubbornness, even in the face of women's intense struggle for equality. No family, including the Olympic Family, can exist without a woman. Coubertin contradicted himself again in his grotesque interpretation of the notion of amateur athlete. Baron de Coubertin's persistent segregation of athletes into amateurs and professionals, undoubtedly based on a class-by-birth system, weakened the Olympic community. He was not able to cope with the growing specter of racism. The founder of the Olympic family in friendship was not even able to keep his own family united in love. But despite his stumbles in private and public life Coubertin mapped out the global route of sport and justified its sense with the necessity of moral revival of humanity.

\section{War as the primary cause of Olympic sport}

Olympic modernism emerged at a time when the civilized nations of Europe suffered a series of cultural defeats. Their experience and memory of consecutive wars did not, however, make them lose their faith in themselves. Wars are started by madmen, and there have been few of them. The madmen can be redeemed; the world can be rebuilt; the Europeans know about this. In their culture of faith, hope and love Europeans are permeated with optimism. After each fall they would be aiming at atonement, and they would be deeply convinced that the redemption of war is possible through "the holy ritual of peace" (R. Scruton) $)^{11}$. They use every opportunity: artistic, religious ${ }^{12}$, political and apolitical, in their global cycle of Olympiads of friendship for peace between all the nations of the world at the sporting level. All Nations in All Games are summoned to take part in the Olympic

\footnotetext{
${ }^{10}$ Early Olympism often lost its way. I call this period proto-Olympism.

${ }^{11}$ See Modernism in art in R. Scruton, An Intelligent Person's Guide to Philosophy, Łódź 2006, Thesaurus. Scruton does not mention Olympic modernism in his book, but it seems the idea of Olympism would be very close to him.

${ }^{12}$ Prayers for peace are innumerable. A few days ago I witnessed crowds of people praying in front of the amazing Jerusalem Altar of the Holy Sacrament for Peace.
} 
sacrum of peace. Winning Olympic medals is secondary; participating is winning. Whoever participates in the Olympic Games is the winner in Olympic humanity, as Man linked by the bonds of friendship becomes pure. Pure Man shows himself and others, who might be unfavorable to the Olympic family, that Olympism is like a life in which the "triumph over the evil of war" is possible (following R. Scruton's reference to modernism in art).

In this context Olympic sport is not sport; it is neither more nor less than sport. The nature of Olympism should not be considered in relation to sport as such. What I mean here is that sport is part of a higher sphere of secular sacrum. Ludic sport, spectator sport and professional sport are inherent parts of the profanum of existence. And it should stay that way, as man of work must reveal himself in sport-play.

Olympic sport is a symbolic response to the literal evil of war. It establishes peace in its own way as there is always a need to redeem the evil of war. St. Augustine noted that the universal pursuit of peace involves a certain paradox: wars are imbedded in human history. ${ }^{13}$ Sport is not what the mindful journalists think - a gathering of a pagan mob, a festival of youth or a vanity fair of business traders. If, however, Olympic modernism ever became its own negation in the form of a spontaneous movement of liberation from moral constraints, legitimized by postmodern ideology, it would be a negation of the ethical ideal of friendship, i.e. it would be collective defiance of order as ordo amicitia pro pace. In consequence, Olympic modernism would deprive itself of the idea of universal good and lose its inherent order-making potential. Whoever then becomes a part of the motley movement against oneself, in which all standards of moral life in love are replaced by liberal aesthetic expressions, he or she becomes incomprehensible to themselves and others, like the proverbial black sheep in the family. Beware the poor in Olympic spirit of peace, as they will never be granted friendship. It will be a great loss to them as well as to the entire Olympic family.

\section{Conclusion}

The Olympic Games of Peace must last as long as there are wars ${ }^{14}$. The primary cause of Olympic sport is the experience of the evil of war. Olympic modernism uses sport as the foundation of its symbolic affirmation of the idea of friendship. It did not create sport, but it has taken great advantage of it, using the physical cultivation and the moral formation of the mighty sports club for free play (ludic sport) or paid play (professional sport). Although the Olympic costs are high, despite all the expenses it is a highly profitable cultural enterprise. The order of friendship for peace, known as Olympic modernism, not only banishes the specter of hatred but also provides culture with sanctity, making everybody's life more perfect.

\footnotetext{
${ }^{13}$ After St. Augustine, Civitas Dei, Book XIX quoted in Father Janusz Szulist: Koncepcja wojny sprawiedliwej św. Tomasz z Akwinu (The concept of just war according to Thomas Aquinas), In Studia Pelplińskie 2007, vol. XXXVIII, p. 340.

${ }^{14}$ I call this rule Law of Olympic peace, see Osoba w pedagogice ciała, Olsztyn 2007, OSW.
} 